\title{
Structural characterization by Nuclear Magnetic Resonance of ozonized triolein
}

\author{
By Maritza F. Díaz ${ }^{1^{*}}$, José A. Gavín ${ }^{2}$ and Jailson B. de Andrade ${ }^{3}$
}

\author{
${ }^{1}$ Department of Ozonized Substances, Ozone Research Center, \\ National Center for Scientific Research, P.O. Box 6412, Havana, Cuba. \\ ( ${ }^{*}$ corresponding author: maritza.diaz@ cnic.edu.cu) \\ ${ }^{2}$ University of the Laguna 38207, Tenerife, Spain. \\ ${ }^{3}$ Federal University of Bahia, Salvador de Bahia, Brazil.
}

\section{RESUMEN}

Caracterización estructural por Resonancia Magnética Nuclear de trioleina ozonizada.

En el presente estudio ha sido caracterizada por RMN la trioleina ozonizada con índice de peróxidos de $739 \mathrm{mmol}$ equiv/kg. La trioleina y la trioleina ozonizada muestran espectros muy similares exceptuando los valores de las resonancias $\delta 9,74 \mathrm{ppm}$ de los protones aldehídicos, y $\delta 5,14$ ppm (protones metínicos de los ozónidos). Otras nuevas asignaciones fueron basadas en las conectividades obtenidas por las constantes de acoplamiento escalar como $\delta$ 2,41 ppm (grupo metilénico alilico a los protones aldehídicos y protones metínicos de los ozónidos) y $\delta 1,67$ ppm (protones metilénicos en posición $\beta$ con respecto a los protones metínicos de los ozónidos). En los espectros ${ }^{13} \mathrm{C}$ y ${ }^{1} \mathrm{H}-{ }^{13} \mathrm{C}$ de la trioleina ozonizada la presencia de ozónidos fue atribuida, respectivamente, por las señales $\delta 104,2$ y $\delta 104,3$ ppm. Una nueva señal en $\delta 43,9$ ppm confirma la presencia de carbono metilénico de ozónidos. Estos resultados indican que la elucidación estructural de triglicéridos ozonizados, ofrece información química relevante relacionada con los aceites vegetales ozonizados.

PALABRAS CLAVE: Aldehído - Ozónidos - Ozonización - Ozono - RMN - Trioleina.

\section{SUMMARY}

Structural characterization by Nuclear Magnetic Resonance of ozonized triolein.

In the present study ozonized triolein with $739 \mathrm{mmol}$ equiv/kg peroxide index is characterized by NMR. The triolein and ozonized triolein show very similar ${ }^{1} \mathrm{H}$ NMR spectra except for the resonances at $\delta 9.74 \mathrm{ppm}$, which correspond to aldehydic protons and $\delta 5.14 \mathrm{ppm}$ (ozonides methylic protons). Other new signal assignments are based on the connectivities provided by the proton scalar coupling constants $\delta 2.41 \mathrm{ppm}$ (methylenic group allylic to aldehydic protons and ozonides methynic protons) and $\delta 1.67 \mathrm{ppm}$ (methylenic protons in $\beta$ position with respect to ozonides methylic protons). From the ${ }^{13} \mathrm{C}$ and ${ }^{1} \mathrm{H}^{-13} \mathrm{C}$ spectrum of the ozonized triolein, the presence of ozonides was confirmed by the signals $\delta 104.2$ and 104.3 ppm, respectively. Other new signals in $\delta 43.9 \mathrm{ppm}$ confirm the presence of methylenic carbon ozonides. From the structural elucidation of ozonated triglycerides, relevant chemical information about ozonated vegetable oil can be found

KEY-WORDS: Aldehydes - NMR - Ozonation - Ozone Ozonides - Triolein.

\section{INTRODUCTION}

Most of the fatty acids in vegetable oil are present as triacylglycerols (triglycerides). The triolein is one of the components of vegetable oils and lipids (Vajda, 1976; Pryor, 1995).

The analytical tools which have been available in recent years include chromatographic techniques. The analysis of triacylglycerol by liquid chromatography is one of the most difficult applications because of the physicochemical properties of these oils such as their thermal instability due to the presence of unsaturated chains. Nowadays, the high-resolution nuclear magnetic resonance (NMR) spectroscopy is a technique used to provide valuable information about the acyl distribution of triacylglycerols of different vegetable oils (.Mannina, 1999; Vlahov, 1998). However, information on the characterization by NMR spectroscopic of the products generated by ozonolysis of triolein is limited.

The reaction of ozone with unsaturated compounds takes place through the known Criegee mechanism (Criegee, 1975; Pryor, 1991). This consists of: an electrophilic attack of ozone at the carbon-carbon double bond, resulting in the 1,2,3 trioxolane or primary ozonide, which rapidly decomposes to give a carbonyl oxide or zwitterion and a carbonylic compound (aldehyde or ketone). In nonparticipating organic solvents, these last two species recombine to give the Criegee ozonides. If water is present, a part of carbonyl oxide reacts with them giving hydroxyhydroperoxides, hydrogen peroxide, and aldehyde and the other carbonyl oxide part recombines with aldehydes to form the Criegee ozonides, but in a smaller amount compared with the reaction in organic solvents (Rietjens, 1987; Freeman, 1979).

Triacylglycerols represent difficult compounds to be studied, due to the presence of three different reaction sites of glycerol backbone which can be esterified with different fatty acids thus producing a complex mixture.

Due to triolein has the same esterified fatty acid in the third position, it was chosen as a model compound to be ozonized. In this study, the products of ozonized triolein were analyzed at a peroxide value of $739 \mathrm{mmol}$-equiv/ $/ \mathrm{kg}$ applying ${ }^{1} \mathrm{H}$, ${ }^{13} \mathrm{C}$ and 2D COSY NMR spectroscopy. 


\section{EXPERIMENTAL SECTION}

\subsection{Materials}

Triolein $95 \%$ purity was supplied by Sigma (USA). Glacial acetic acid, chloroform, potassium iodide, sodium thiosulfate and starch were purchased from MERCK (Germany).

\subsection{General ozonization procedure}

Triolein $(3 \mathrm{~mL})$ were introduced into a reactor with bubbling ozone gas and placed in a water bath at room temperature. The reaction with ozone was continued for 8 minutes at applied ozone doses of $147.7 \mathrm{mg} / \mathrm{g}$. Ozonized triolein was stored between 2-8 ${ }^{\circ} \mathrm{C}$ before further analysis for NMR.

\subsection{Ozone generation}

Ozone was generated by passing oxygen through a 12-02 model ozone generator from the Trailigaz Company (France) at a fixed voltage (170 $\mathrm{V}$ ) and a constant flow rate of $42 \mathrm{~L} / \mathrm{h}$. The resulting initial ozone concentration was $69 \mathrm{mg} \mathrm{L}^{-1}$ determined by an Ozomat model equipment from the Anseros Company (Germany).

\subsection{Measurement of NMR spectra}

${ }^{1} \mathrm{H},{ }^{13} \mathrm{C}$, DEPT 135 and 2D COSY NMR spectra were obtained in a BRUKER 9.4 Tesla AVANCE Spectrometer with $\mathrm{CDCl}_{3}$ as solvent and tetramethylsilane (TMS) as internal reference. The H NMR spectra were obtained using a $5 \mathrm{KHz}$ spectral width, 60 degree pulse width (5 ms), 8 scans, and 64 Kbytes of memory ${ }^{13} \mathrm{C}$ NMR spectra were recorded operating at $100 \mathrm{MHz}$ and were obtained using the following acquisition parameter: $64 \mathrm{~K}$ acquisition point; spectral width 220 ppm; relaxation delay, 2 s; a total of 800 scans were collected for the sample with a $45^{\circ}$ excitation pulse. The experiment (distortionless enhancement by polarization transfer, DEPT) was carried out using variable pulse $\theta=135^{\circ}$. The $2 \mathrm{D}{ }^{1} \mathrm{H}-{ }^{1} \mathrm{H}$ correlation spectroscopy (COSY) and Heteronuclear Simple Quantum Correlation (HSQC) spectra were obtained with a digital resolution of $5.425 \mathrm{~Hz}$ after zero filling. Zero filling (one) was done in the F1 dimension of a $512 \times 512$ matrix, the data were 2D transformed, and the magnitude spectra multiplied by a sine window in each dimension and made symmetrical along the diagonal (Croasmun, 1987).

\subsection{Determination of the peroxide index (IP)}

The peroxide index represents the number of mmol-equivalents of active oxygen which expresses the amount of peroxide contained in $1000 \mathrm{~g}$ of the substance. Briefly, $5 \mathrm{~g}$ of sample were mixed with 30 volumes of glacial acetic, 20 volumes of chloroform and $0.5 \mathrm{~mL}$ of saturated potassium iodine solution. The mixture was shaken for exactly 1 minute, mixed with $30 \mathrm{~mL}$ of water and slowly titrated; shaking continuously, with $0.01 \mathrm{M}$ sodium thiosulphate until the yellow color almost disappeared. The peroxide index values were obtained from the expression $10 \mathrm{v} / \mathrm{w}$, where $\mathrm{v}$ is the volume of sodium thiosulphate in $\mathrm{mL}$ consumed in the titration, and $\mathrm{w}$ is the weight in $\mathrm{g}$ of substance taken (B.P., 2000). The peroxide index $(\mathrm{Pl})$ was expressed in mmol-equiv/kg.

\section{RESULTS AND DISCUSSION}

The aim of this study was to assess the products of ozonized triolein, specifically, oleic acids from glycerol backbone. Since vegetable oils consist almost entirely of triglyceride molecules, no appreciable difference was anticipated between the chemical shift values of these vegetable oils and their component fatty acids (Woodbury, 1998). In our experiment for preparation of ozonated triolein, about $147.7 \mathrm{mg} / \mathrm{g}$ of ozone was absorbed per $3 \mathrm{~mL}$ of triolein which seemed to be enough to obtain ozonized triolein with $739 \mathrm{mmol}$-equiv/ $\mathrm{kg}$ of peroxide index. Scheme 1 shows that possible ozonides, and aldehydes can be obtained in ozonized triolein. For a better explanation, table I shows the chemical shift and probable structures of the functional group of these oxygenated compounds.

Figure 1a shows the ${ }^{1} \mathrm{H}$ NMR spectrum from triolein, presenting a single peak at $\delta 7.2 \mathrm{ppm}$ which belongs to the chloroform-d, multiplet peaks at $\delta 5.3 \mathrm{ppm}$ which belong to olefinic signals from the fatty acid and, $\delta 5.2 \mathrm{ppm}$ (triplet from methynic group of glycerol in sn-2 position). Other signals present are $\delta 4.1$ to $\delta 4.2$ ppm (doublets belonging to glycerol protons in sn 1,3 position); $\delta 2.3 \mathrm{ppm}$ (triplet from methylenic groups in $\alpha$ position with respect to carbonylic group); $\delta 1.9 \mathrm{ppm}$ (multiplet from methylenic group in both sides of olefinic protons); $\delta 1.6 \mathrm{ppm}$ (multiplet from methylenic group in $\beta$ position with respect to carbonylic group); $\delta 1.2 \mathrm{ppm}$ (signal from methylenic groups in fatty acid chain); and $\delta 0.87 \mathrm{ppm}$ (triplet from terminal methyl group). These signals coincided with those reported in the NMR study of olive oil (Vlahov, 1999).

The ${ }^{1} \mathrm{H}$ NMR spectrum from ozonated triolein is displayed in figure $1 \mathrm{~b}$. This spectrum has the same observed signals in triolein (figure 1a) and additionally other eight signals at $\delta 9.7 \mathrm{ppm}$ y ppm (triplet from aldehydic protons), $\delta 5.1 \mathrm{ppm}$ (multiple from ozonides), $\delta 2.41 \mathrm{ppm}, \delta 1.67 \mathrm{ppm}$, and $\delta 1.39$ ppm (multiple from formed ozonides protons), see table 1 . These additionally formed signals are oxygen compounds responsible for the germicide effect of coconut oil and ozonized sunflower oils (Díaz, 2001; Díaz, 2005a). The proton signals of olefinic double bond, ozonides and glycerol in the sn-2 and sn-1,3 positions can be observed in figure 2 with the wide spectral range of $3.6-5.4 \mathrm{ppm}$. The 


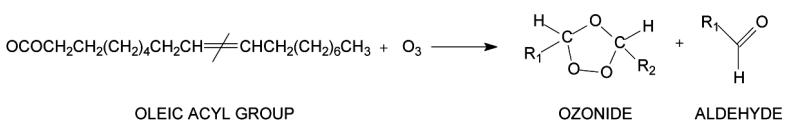

OZONIDES
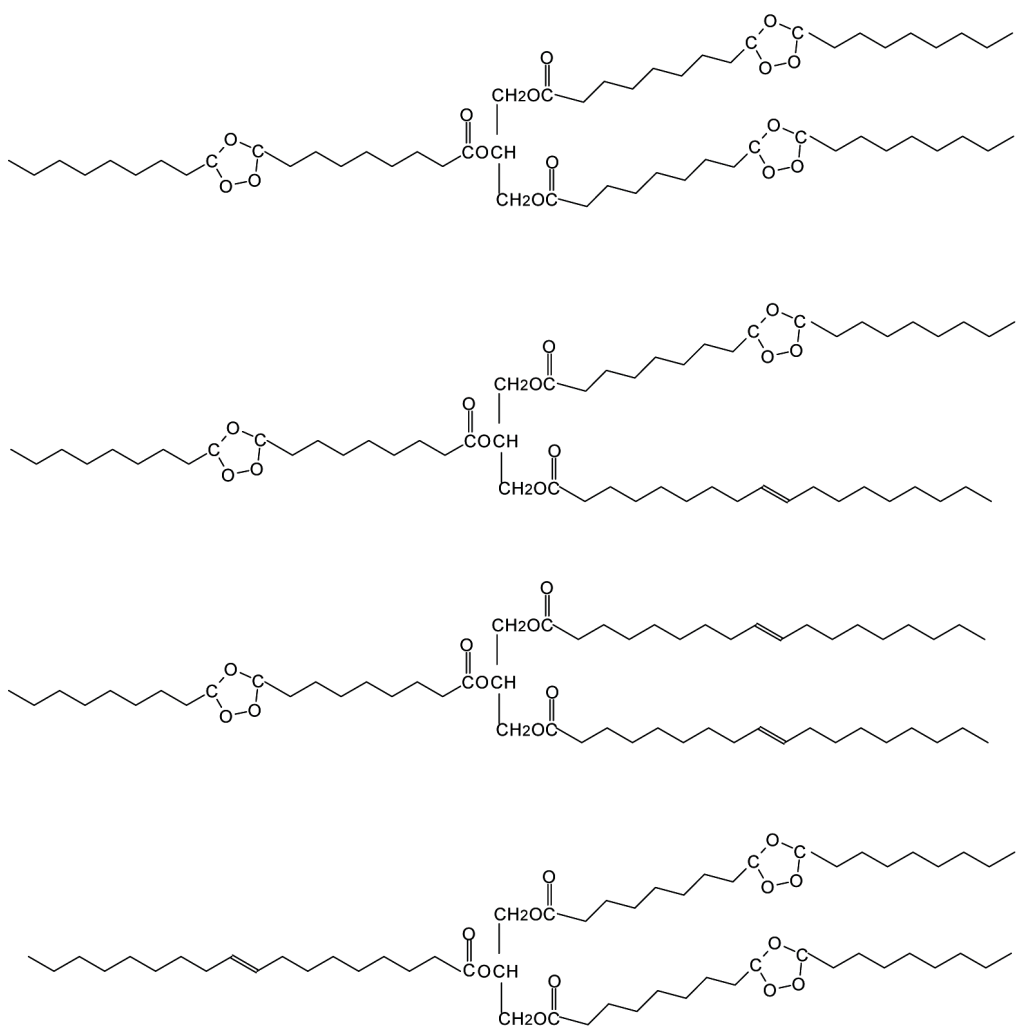

\section{ALDEHYDES}
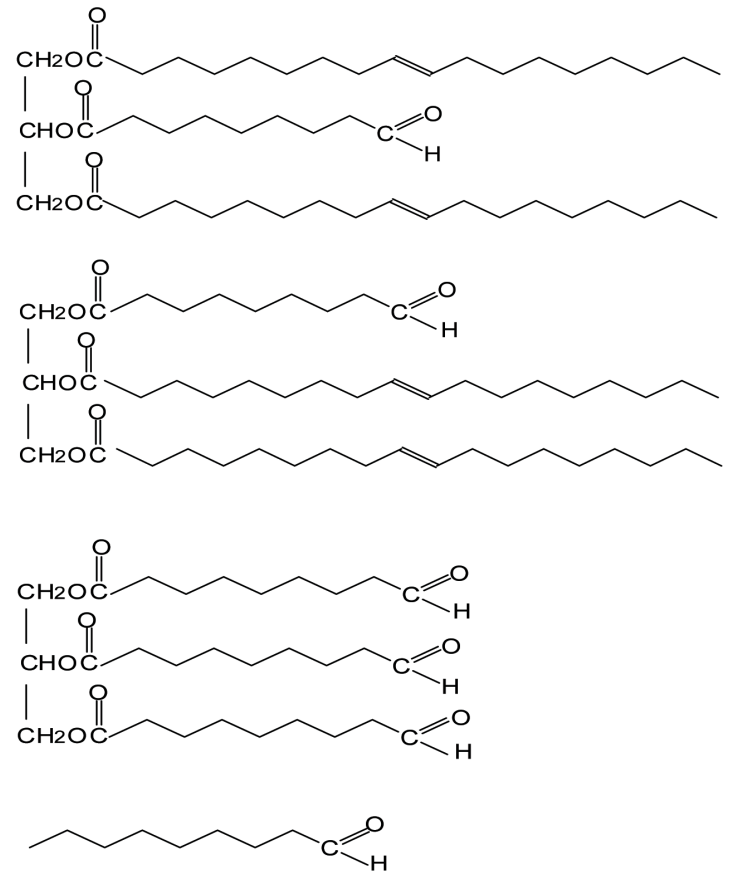

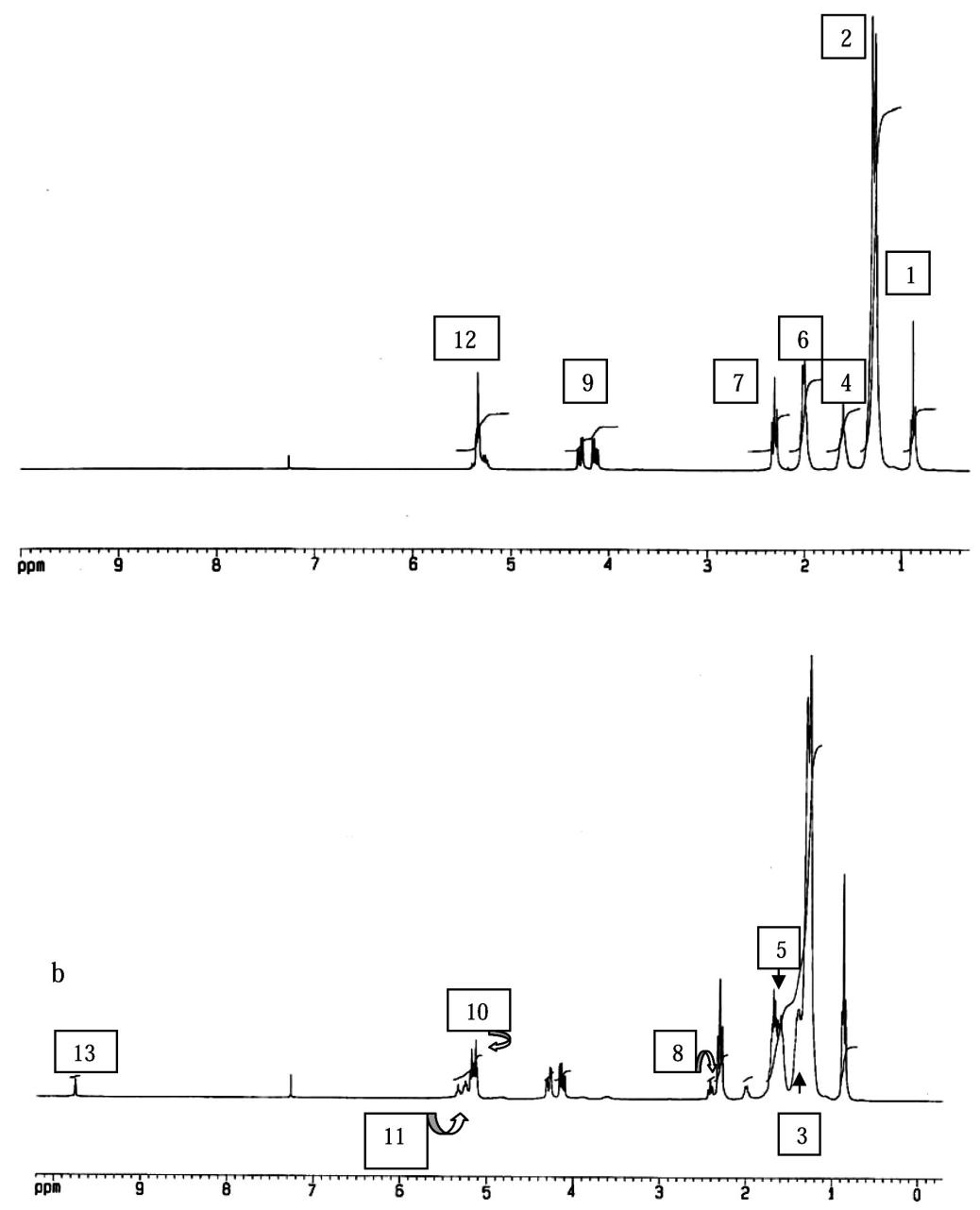

Figure 1.

${ }^{1} \mathrm{H}$ NMR spectra in $\mathrm{CDCl}_{3}$ in 9.4 Tesla equipment. a) Triolein, b) Ozonized triolein.

intensities of olefinic proton signals $\delta 5.3 \mathrm{ppm}$ (Figure 1a) decreased during ozonization reactions (Figure 1b y 2) (Díaz, 1997; Díaz, 2003), but they did not disappear completely. This result indicates that some double bonds did not react with ozono. For this reason, Scheme 1 shows how possible ozonides, and aldehydes can be obtained in ozonized triolein with $739 \mathrm{mmol}$-equiv $/ \mathrm{kg}$ of peroxide index. Another aspect observed in the figure 2 is the assignation of doublets signals belonging to glycerol in sn-1,3 positions at $\delta 4.14$ to $\delta 4.29 \mathrm{ppm}$. These signals presented the same value of ${ }^{2} \mathrm{~J}$ coupling constant $11.89 \mathrm{~Hz}$. This result demonstrates that both chemical shifts correspond to the same methylenic signals in position sn-1,3 of glycerol (Table 1).

The ${ }^{13} \mathrm{C}$ NMR spectrum of triolein contains the resonance of carbons from the triglyceride fraction of vegetable oil, i.e. the fatty acid resonance (Vlahov, 1998), (Wollenberg, 1990). The different signals are resolved on the basis of chain double bond number: oleoyl chains (C18:1 9c). The chemical shift can be predicted by the additive relationship for the normal alkanes based upon the number of $\alpha, \beta$ and $\gamma$ carbon atoms in the molecule (Giovanna, 1998). Figure 3 shows the ${ }^{13} \mathrm{C}$ and DEPT NMR spectra from ozonized triolein. The terminal methyl carbon shift of three chains $\mathrm{C}-18$ is found at $\delta 14.1 \mathrm{ppm}$. Three methylene groups are readily identified: $\mathrm{C}-17$ at $\delta 22.6$ and $\delta 22.1 \mathrm{ppm}$ methylenic acylic chains; C-3 at $\delta 24.7 \mathrm{ppm}$ methylenic group in $\beta$ position with respect to the carbonylic group; $\mathrm{C}-11(\mathrm{O})$ and $\mathrm{C}-8(\mathrm{O})$ at $\delta 27.1$ ppm allylic carbons of oleoyl chains; $\delta$ 28.9-29.7 ppm methylenic groups in fatty acid central chain; C-16 at $\delta 31.8$ methylenic acylic chains $\omega$. The composition of mono-, di- and triglycerides was determined by means of the glycerol carbon resonance (Vlahov, 1996). The 1(3)-and 2- glycerol carbons of triglycerides resonate at $\delta=62.1 \mathrm{ppm}$ and $\delta=68.9 \mathrm{ppm}$, respectively. The resonances C9 and $\mathrm{C}-10$ at $\delta 129.7 \mathrm{ppm}$ and $\delta 130 \mathrm{ppm}$ corresponding to oleoyl unsaturated carbons between 2- and 1(3) positions of glycerol and carbonyl carbons at $\delta 172.8 \mathrm{ppm}$ belonging to 2glycerol chain positions and $\delta 173.2 \mathrm{ppm}$ belonging to 1 (3) glycerol chain positions were also identified. 
Table 1

Chemical shift of group functional of ozonized triolein.

\begin{tabular}{|c|c|c|c|}
\hline No. Señal & Functional Groups Structures & $\begin{array}{l}\text { Chemical Shift } \\
\delta^{1} \mathrm{H}(\mathrm{ppm})\end{array}$ & $\begin{array}{c}\text { Chemical Shift } \\
\delta{ }^{13} \mathrm{C}(\mathrm{ppm})\end{array}$ \\
\hline 1 & 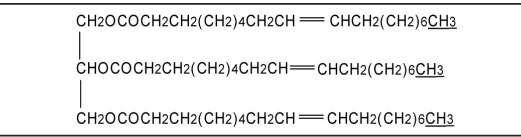 & 0.87 & 14.1 \\
\hline 2 & 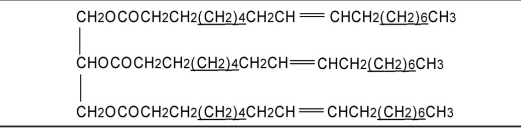 & 1.28 & 28.9-29.7 \\
\hline 3 & $\mathrm{R} 1\left(\mathrm{CH}_{2}\right) \mathrm{n}$ & 1,39 & $23-24$ \\
\hline 4 & 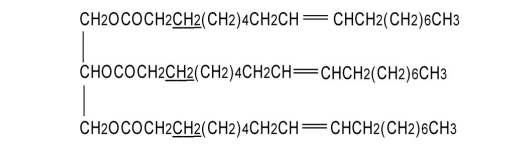 & 1.60 & 24.7 \\
\hline 5 & 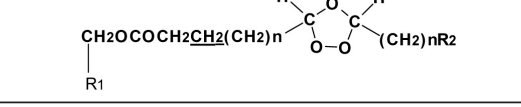 & 1.67 & 32.3 \\
\hline 6 & 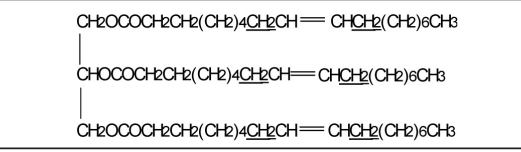 & 1.98 & 27.1 \\
\hline 7 & 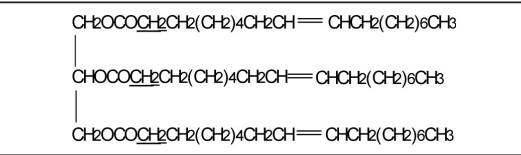 & 2.30 & 34,1 \\
\hline 8 & $\left.\right|_{\mathrm{R} 1} ^{\mathrm{CH}}$ & 2.41 & 43.9 \\
\hline 9 & $\begin{array}{l}\mathrm{CH}_{2} \mathrm{OCOCH}_{2} \mathrm{CH}_{2}(\mathrm{CH} 2) 4 \mathrm{CH}_{2} \mathrm{CH}=\mathrm{CHCH}_{2}\left(\mathrm{CH}_{2}\right) 6 \mathrm{CH}_{3} \\
\mathrm{CHO}_{2} \mathrm{CH}_{2} \mathrm{OCOCH}_{2} \mathrm{CH}_{2}\left(\mathrm{CH}_{2}\right) 4 \mathrm{CH}_{2} \mathrm{CH}_{2}=\mathrm{CHCH}_{2}\left(\mathrm{CH}_{2}\right) 6 \mathrm{CH}_{3}\end{array}$ & $4.14-4.29$ & 62.1 \\
\hline 10 & 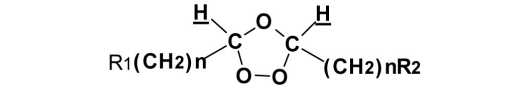 & 5.14 & 104.2-104.3 \\
\hline 11 & $\begin{array}{l}\mathrm{CH}_{2} \mathrm{OCOCH}_{2} \mathrm{CH}_{2}\left(\mathrm{CH}_{2}\right) 4 \mathrm{CH}_{2} \mathrm{CH}=\mathrm{CHCH}_{2}\left(\mathrm{CH}_{2}\right) 6 \mathrm{CH}_{3} \\
\frac{\mathrm{CHO} \mathrm{COCH}_{2} \mathrm{CH}_{2}(\mathrm{CH} 2) 4 \mathrm{CH}_{2} \mathrm{CH}=\mathrm{CHCH}_{2}(\mathrm{CH} 2) 6 \mathrm{CH}_{3}}{\mathrm{CH}_{2} \mathrm{OCOCH} 2 \mathrm{CH}_{2}\left(\mathrm{CH}_{2}\right) 4 \mathrm{CH}_{2} \mathrm{CH}=\mathrm{CHCH}_{2}\left(\mathrm{CH}_{2}\right) 6 \mathrm{CH}_{3}}\end{array}$ & 5.26 & 68.9 \\
\hline 12 & 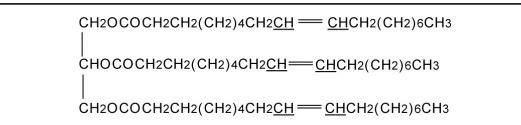 & 5.33 & 129.7-130.0 \\
\hline 13 & $\mathrm{R}_{1} \mathrm{C}=\mathrm{O}$ & 9.74 & 202.9 \\
\hline
\end{tabular}

$R_{1}$ and $R_{2}$ can be the represented structures in scheme 1 for ozonides and aldehydes.

However, a new group of signals was found in the spectra from ozonized triolein. Signals at $\delta 23$ to $24 \mathrm{ppm}, \delta 32.3 \mathrm{ppm}$ and $\delta 43.9 \mathrm{ppm}$ belong to methylenic carbons of ozonides and aldehyde. Other signals found were of methynic carbons corresponding to ozonides at $\delta 104.2$ and $\delta 104.3$ ppm (Table 1).

The DEPT experiment was applied to obtain ${ }^{13} \mathrm{C}$ NMR spectra over the whole carbon-13 frequency range with the purpose of producing ${ }^{13} \mathrm{C}$ NMR resonance for a more precise interpretation. The only drawback was the loss of carbonyl carbon resonance, which is not detected by the DEPT sequence (Freeman, 1988).

The assignments of the various signals were accomplished by using a combination of 2D COSY techniques ${ }^{1} \mathrm{H}-{ }^{-} \mathrm{H}$ and $\mathrm{HSQC}$ (Figure 4 to 7 ). To explain the detailed interpretation of the ${ }^{1} \mathrm{H}-{ }^{1} \mathrm{H}$ NMR 


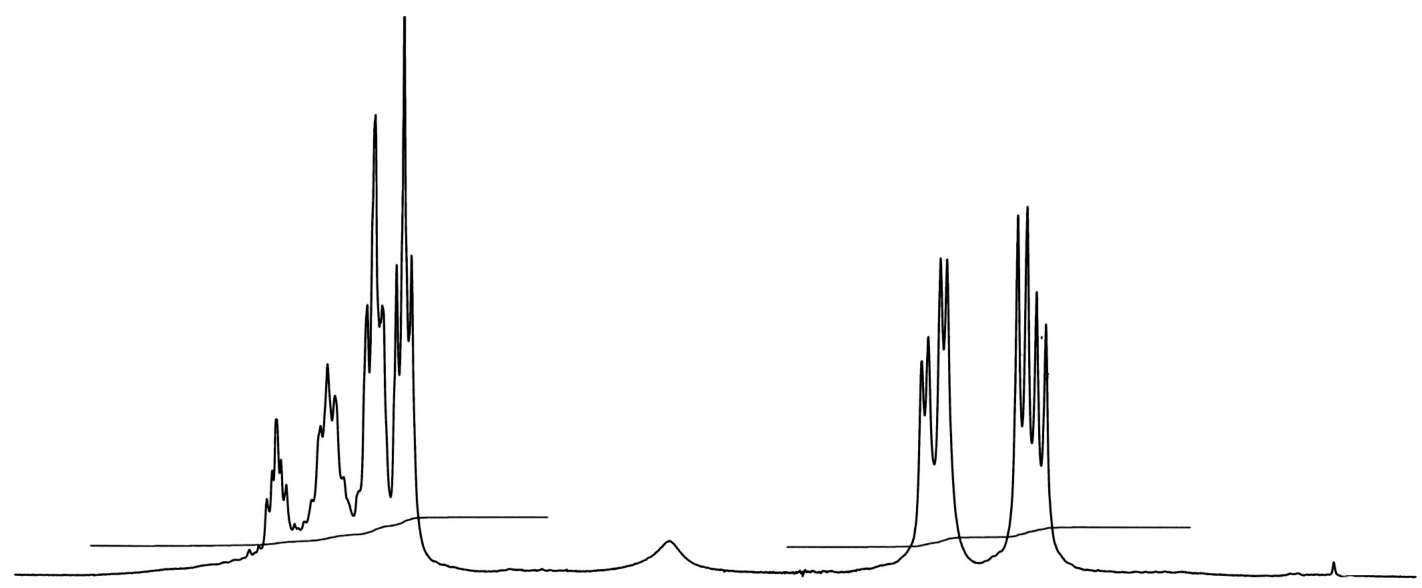

Figure 2.

${ }^{1} \mathrm{H}$ NMR spectrum of ozonized triolein relative to spectral range 3.6-5.4 ppm.in CDCL3 in 9.4 Tesla equipment.
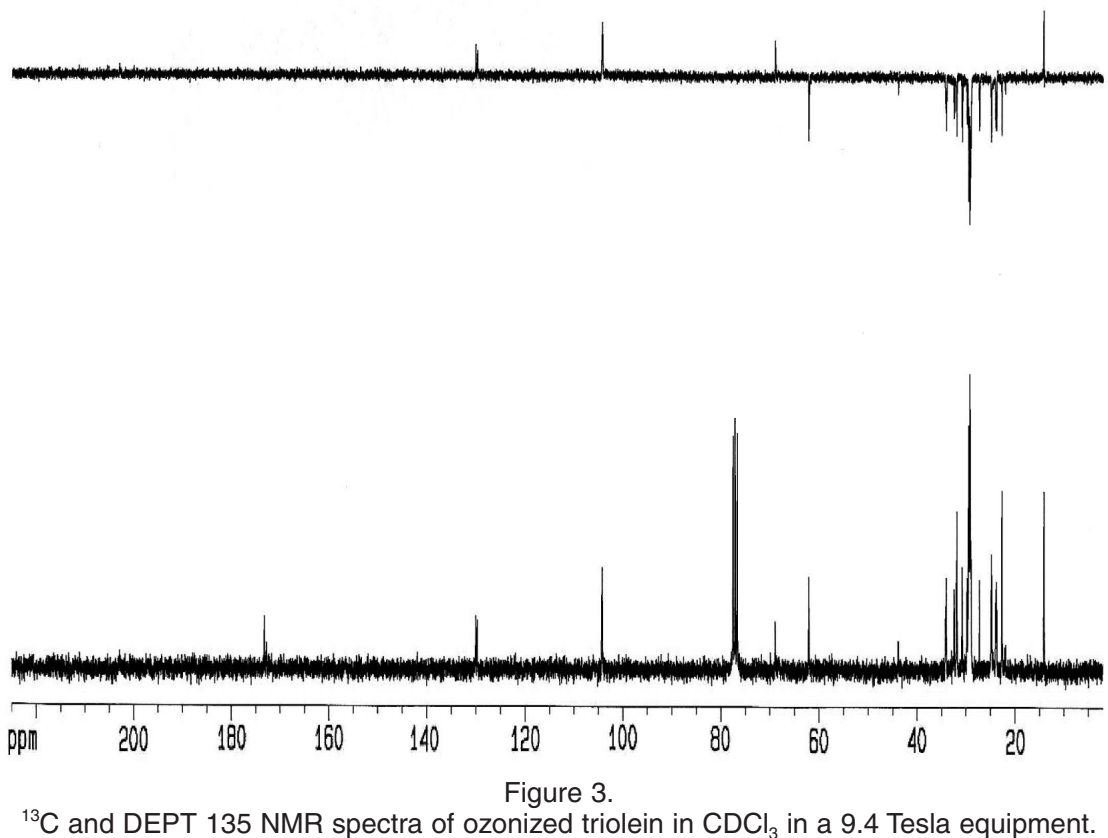

COSY spectra, the ${ }^{1} \mathrm{H}$ NMR spectrum showed four new signals: $\delta 5.1 \mathrm{ppm}, \delta 2.41 \mathrm{ppm}, \delta 1.67 \mathrm{ppm}$ and $\delta 1.39 \mathrm{ppm}$. From the ${ }^{1} \mathrm{H}-{ }^{1} \mathrm{H}$ NMR COSY correlation spectrum (Figure 4), it was clear that the multiplet a $\delta 2.41 \mathrm{ppm}$ (from methylenic group) was correlated to the $\delta 9.7 \mathrm{ppm}$ (aldehydic protons) and $\delta 5.1 \mathrm{ppm}$ from ozonides was correlated to the $\delta 2.41 \mathrm{ppm}, \delta$ 1.67 and $\delta 1.39$ ppm (multiplet from formed ozonides protons) (Figure 5). Also in figure 6 the ${ }^{1} \mathrm{H}$ ${ }^{1} \mathrm{H}$ NMR COSY spectra in the range the 4-6 ppm can be observed, where the triplet from methynic group of glycerol in sn-2 position at $\delta 5.2 \mathrm{ppm}$ is correlated with the doublets belonging to glycerol protons in sn 1,3 position at $\delta 4.1$ to $\delta 4.2 \mathrm{ppm}$. This result achieved one unequivocal assignment of glycerol signals.
The ${ }^{13} \mathrm{C}$ spectrum showed various new signals: $\delta$ 104.2-104.3 ppm; $\delta 43.9$ ppm; $\delta 23.4$ ppm and 23.8 ppm. From the HSQC correlation spectrum (Figure 7), we observed that the multiplet at $\delta \mathrm{H} 5.3 \mathrm{ppm}$ correlated to the carbon atoms $\delta$ C 129.7-130.0 ppm, spectral region of methynic carbons near unsaturated carbons. The multiplet $\delta \mathrm{H}=5.1 \mathrm{ppm}$ correlated to the carbon atoms $\delta C$ 104.2-104.3 ppm, they belong to carbons methynic from ozonides and oligomers, these assignations are similar to those reported from ozonated olive oil (Miura,.2001; Díaz, 2005b). Signal of methylenic carbon at $\delta \mathrm{C} 43.9$ ppm correlated to the $\delta \mathrm{H} 5.1 \mathrm{ppm}$ of ozonides. The last methylenic signals at $\delta \mathrm{H} 1.39$ ppm, belonging to ozonides, correlated to the carbon atoms at $\delta \mathrm{C} 23.7$ and $23.9 \mathrm{ppm}$. 


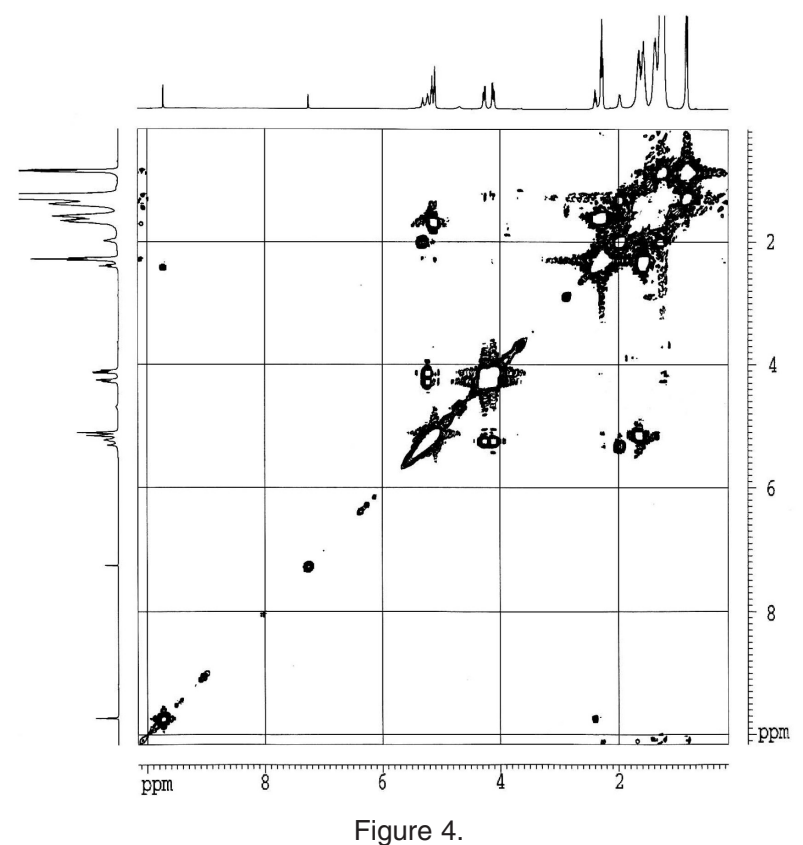

${ }^{1} \mathrm{H}-{ }^{1} \mathrm{H}$ NMR correlation spectroscopy 2D NMR spectrum of ozonized triolein in 9.4 Tesla equipment.

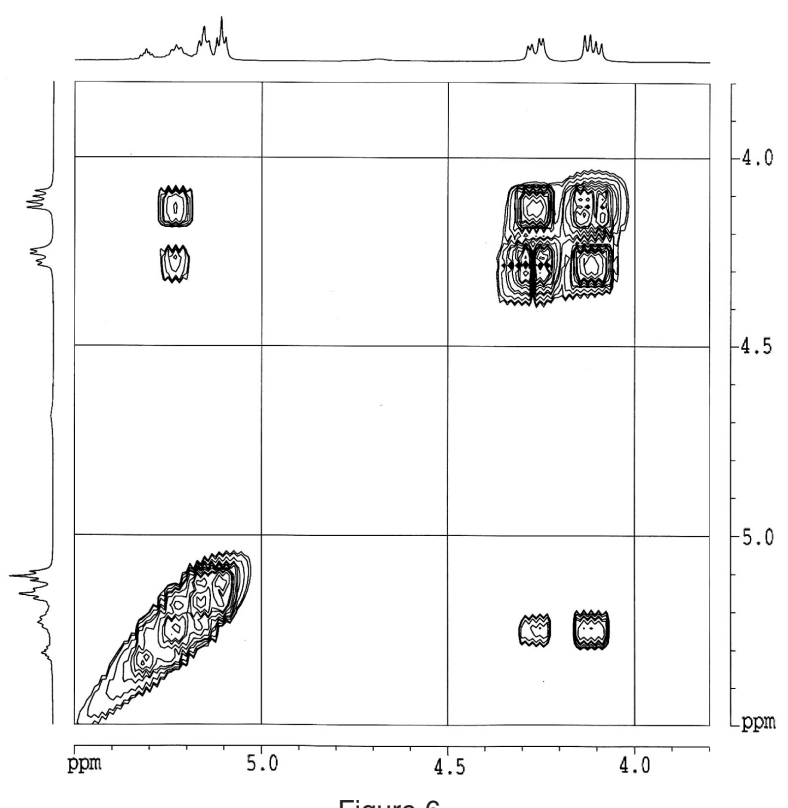

Figure 6.

${ }^{1} \mathrm{H}-{ }^{1} \mathrm{H}$ NMR correlation spectroscopy 2D NMR spectrum of ozonized triolein, relative to spectral range 4-6 ppm in 9.4 Tesla equipment.

High-resolution ${ }^{1} \mathrm{H}$ NMR spectroscopy has had limited use in fatty acid analysis owing to the small range of chemical shifts covered by protons, which resulted in the small number of signals in the proton spectrum. The splitting patterns of proton signals, however, can provide unique structural properties of vegetable oils under investigation (Lie, 1997).

In the structural elucidation of the ozonized triolein (Table 1), the assignments of various signals (ozonation products) were accomplished by using a combination of 2D COSY techniques $\left({ }^{1} \mathrm{H}-{ }^{-1} \mathrm{H}\right.$ and $\mathrm{HSQC}$ ) with ${ }^{1} \mathrm{H}$ and ${ }^{13} \mathrm{C}$ NMR spectra. In this study the ozonation products were well characterized as

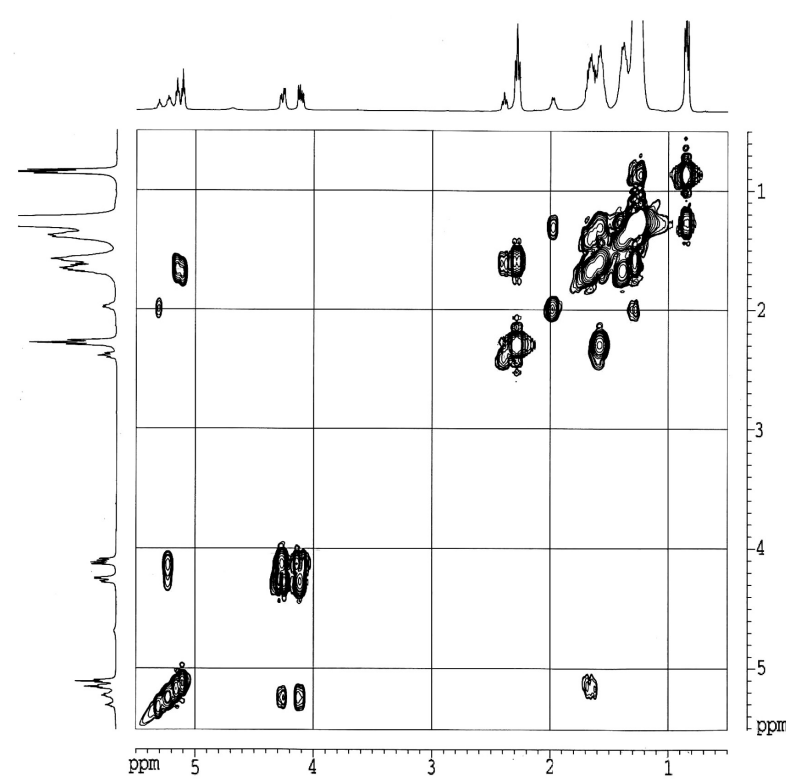

Figure 5.

${ }^{1} \mathrm{H}-{ }^{1} \mathrm{H}$ NMR correlation spectroscopy 2D NMR spectrum of ozonized triolein, relative to spectral range $0-5.5 \mathrm{ppm}$ in 9.4 Tesla equipment.

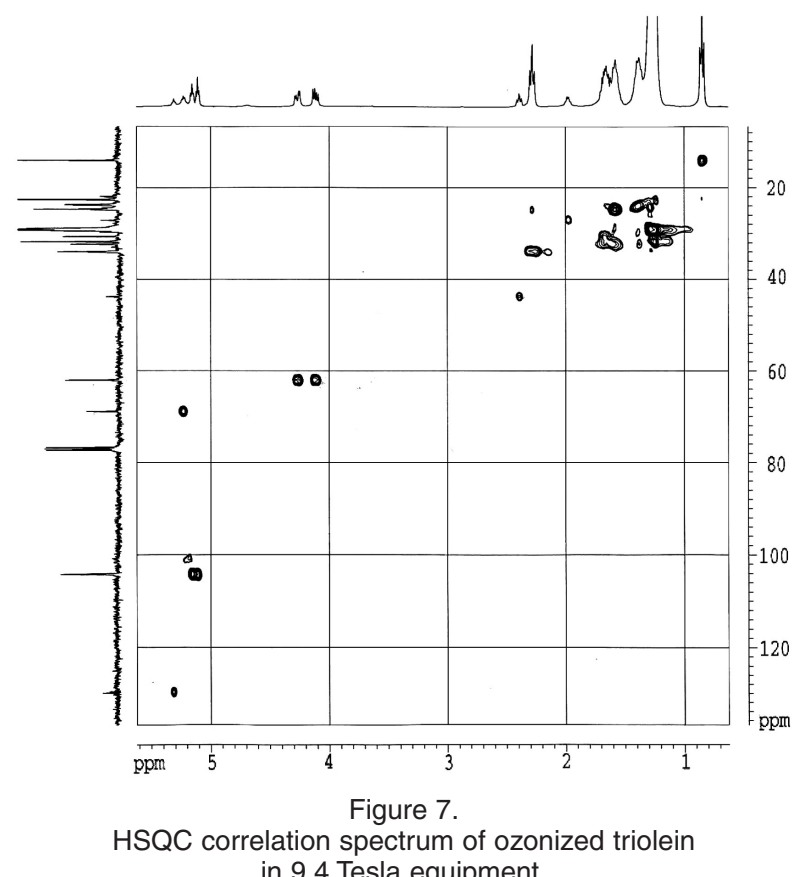

ozonides and aldehydes present in ozonized triolein. The ozonides are oxygenated compound with biological activity which has been demonstrated by (Diaz, 2001). The elucidation and chemical characterization of this ozonized model compound is important for new ozonation strategies with vegetable oil.

\section{ACKNOWLEDGEMENT}

We wish to thank CYTED and CITMA-CNPq for providing financial support. Appreciation is expressed 
to Dr. Angel Gutiérrez Ravelo, University of the Laguna, Tenerife, for his collaboration in this work.

\section{BIBLIOGRAPHY}

British Pharmacopeia. 2000b. Peroxide Value, Appendix $\mathrm{XF}, 1 \mathrm{~A}, 1 \mathrm{~B}$.

Criegee R. 1975. Mechanism of Ozonolisis. 14 Ed., Angewandte Chemie Int. England.

Croasmun W.R, Carlson M.K. 1987. Two-Dimensional NMR Spectroscopy. Applications for Chemists and Biochemists. VCH Publishers, Inc., New York, USA.

Díaz M, Alvarez I, Vélez H, Hernández F, Ledea $O$, Molerio J. 1997. ${ }^{1} \mathrm{H}$-NMR Studies

of the Ozonation of Methyl Oleate. Bol. Soc. Chil. Quím. 42, 349-353.

Díaz M, Lezcano I, Molerio J, Hernández F. 2001. Spectroscopic characterization of ozonides with biological activity. Ozone Sci. Eng. 23, 35-40.

Díaz M, Hernández F, Ledea O, Molerio J, Sazatornil J. 2003. 1H NMR study of methyl linoleate ozonation. Ozone Sci. Eng. 25 (2), 121-126.

Díaz M, Núñez N, Quincose D, Díaz W, Hernández F. 2005a. Study of Three Sistems of Ozonized Cocunut Oil. Ozone Sci. Eng. 27 (2), 1-5.

Díaz M, José Gavin, Ledea O, Hernández F, Alaiz M, Garcés R. 2005b. Spectroscopic characterization of ozonated sunflower oil. Ozone Sci. Eng., 27 (3), 247253.

Freeman B.A, Sharman M.C, Mudd J.B. 1979. Reaction of Ozone with Phospholipid Vesicles and Human Erythrocyte Grosts. Arch. Biochem. Biophys. 197, 264-272.

Freeman R. 1988. A Handbook of Nuclear Magnetic Resonance. Longman Group UK Limited, London.

Giovanna V. 1998. Use of ${ }^{13} \mathrm{C}$ Nuclear Magnetic Resonance Spectroscopy to Study the Triglyceride Fraction of Vegetable Oils. Recent Res. Devel. In Oil Chem. 2, 189-202.

Lie Ken Jie M.S.F, Mustafa J. 1997. High-Resolution Nuclear Magnetic Resonance Spectroscopy -Application to Fatty Acids and Triacylglycerols. Lipids 32 (10), 1019-1034.
Mannina L, Luchinat C, Emanuele M.C, Segre A. 1999. Acyl Positional Distribution of Glycerol Tri-Esters in Vegetable Oils: a ${ }^{13} \mathrm{C}$ NMR Study. Chem. Phys. Lipids 103, 47-55.

Miura T, Suzuki S, Sakurai S, Matsumoto A, Shinriki N. 2001. Structure Elucidation of Ozonated Olive Oil. Proceedings of the $15^{\text {th }}$ World Congress London. Medical Therapy Conference, 72-76.

Pryor W.A, Das B, Church D.F. 1991. The Ozonation Unsaturated Fatty Acids: Aldehydes and Hydrogen Peroxide as Products and Possible Mediators of Ozone Toxicity. Chem. Res. Toxicol. 4, 341-348.

Pryor W.A, Squadrito G.L, and Friedman M. 1995. The Cascade Mechanism to Explain Ozone Toxicity. The Role of Lipid Ozonation Products. Free Radic. Biol. Med. 19(6), 935-941.

Rietjens I.M.C.M, Lemmink H.H, Alink G.M, Van Bladeren P.J. 1987. The Role of Glutathione and Glutathione Stransferases in Fatty Acid Ozonide Detoxification. Chem. Biol. Interactions 62, 3-14.

Vajda O.I, Saenz T.W. 1976, Química de los Alimentos, ch.1, Editorial Científico Técnico, La Habana, Cuba.

Vlahov G. 1996 The Structure of Triglycerides of Monovarietal Olive Oils: $A{ }^{13} \mathrm{C}$ Comparative Study. Fett/Lipid 98, 203-205.

Vlahov G. 1998. Use of 13C Nuclear Magnetic Resonance Spectroscopy to Study the Triglyceride Fraction of Vegetable Oils. Recent Res. Devel. In Oil Chem. 2, 189-202.

Vlahov G. 1999. Application of NMR to the Study of Olive Oils. Progress in Nuclear Magnetic Resonance Spectroscopy 35, 341-357.

Wollenberg K.F. 1990. Quantitative High-Resolution ${ }^{13} \mathrm{C}$ Nuclear Magnetic Resonance of the Olefinic and Carbonyl Carbons of Edible Vegetable Oils. J. Am. Oil. Chem. Soc. 67, 487-494.

Woodbury S.E, Evershed R.P, Rossell J.B. 1998. $\delta{ }^{13} \mathrm{C}$ Analyses of Vegetable Oil Fatty Acid Components, Determined by Gas Chromatography-CombustionIsotope Ratio Mass Spectrometry, After Saponification or Regiospecific Hydrolysis. J. Chromatogr. A. 805, 249-257.

Recibido: 19/1/08 Aceptado: 26/2/08 